\title{
Different proliferation patterns in breast cancer: AgNOR measurements in ER-negative and ER-positive tumor cells
}

\author{
Lukas Günther $^{\mathrm{a}, *}$, Peter Hufnagl ${ }^{\mathrm{b}}$, \\ Klaus-Jürgen Winzer ${ }^{\mathrm{c}}$ and Hans Guski ${ }^{\mathrm{b}}$ \\ ${ }^{a}$ Department of Surgery, University of Heidelberg, \\ Heidelberg, Germany \\ ${ }^{\mathrm{b}}$ Institute of Pathology, Charité Hospital, \\ Humboldt-University Berlin, Germany \\ ${ }^{\mathrm{c}}$ Department of Surgery, Charité Hospital, \\ Humboldt-University Berlin, Germany
}

Received 2 November 1999

Accepted 11 September 2000

The relation between estrogen receptors (ER) and argyrophilic nucleolar organizer regions (AgNORs) in situ within human breast cancer cells was analyzed. For AgNOR measurements in 49 invasive breast carcinomas, a new reproducible staining method for dual demonstration of ER and AgNORs was applied. Quantitative AgNOR variables were determined in ER-positive and ER-negative tumor cells by digital image analysis. The relationships between AgNOR parameters of ER-positive and ER-negative cells and other prognostic factors of breast cancer [Bloom-RichardsonGrading and growth fraction (Ki-67 index)] were investigated. A higher AgNOR content in ER-negative cells and a special clustering phenomenon in ER-positive tumor cells were found. Correlation with other criteria of malignant potential could be exclusively demonstrated for ER-negative cells. ER-negative cells of breast cancer can be characterized as the more malignant and possibly prognosis-dictating cell fraction. Thus, ER-negative cells probably contribute more to the progression of the tumor disease and furthermore to the prognosis than ER-positive cells. We recommend measurement AgNORs exclusively in ER-negative cells of breast cancer.

Keywords: Breast cancer, AgNORs, estrogen receptors, double staining, immunohistochemistry, image analysis

\footnotetext{
*Corresponding author: Lukas Günther, M.D., Immunobiology Research Center, Beth Israel Deaconess Medical Center, Harvard Medical School, 99 Brookline Ave., \#370, Boston, MA 02215, USA.
}

\section{Introduction}

For adequate therapy of tumor disease, an accurate establishment of the prognosis is required. In breast cancer, the most precise and routinely used prognostic factors are (a) tumor staging (TNM), (b) grading according to Bloom and Richardson [1,2] and (c) hormone receptor status $[3,4]$. Considering both clinical and histological criteria, there are no exact predictors of prognosis in breast cancer so far. Beside the search for new prognostic factors, the improvement of the efficiency of existing parameters is focus of tumor research.

Nucleolar organizer regions (NORs) are dot-like substructures of the nucleolus during the interphase located in the fibrillar nucleolar component. NORs are chromosomal segments containing loops of ribosomal DNA (rDNA) [5]. Histological demonstration of NORs is carried out by staining highly argyrophilic NOR-associated proteins (NORAPs) by a silver staining method [6]. Staining modifications by Ploton et al. 1986 [7] were the starting point of widespread investigations of AgNORs in diagnostic tumor pathology. The application of digital image analysis for measuring AgNORs was first introduced in 1989 [8,9] and is now considered to be the method of choice [10]. By use of an image analysis system, nuclei and the AgNORs inside can be segmented, counted and measured. These measurements are characterized as being highly precise and reproducible [11]. Parameters for the histological quantification of AgNORs describe amount, size and the spatial distribution within the nucleus [9]. AgNOR variables are best assigned to proliferation [12]. Additionally, information on tumor differentiation [12] and prognosis $[13,14]$ is given.

Today, the assessment of the estrogen receptor status is carried out routinely. Estrogen receptors are found in $60-80 \%$ of all breast cancers. The expression of hormone receptors is a marker of a higher tumor differen- 
tiation [15] and also helps to detect breast cancer patients who can benefit from endocrine therapy $[4,16]$. Prognostic information is also provided [3,4,17,18]. Immunohistochemical approaches like the EstrogenReceptor-Immuno-Cytochemical-Assay (ER-ICA) visualize receptors directly within the context of the tissue.

AgNOR parameters and ER-status characterize different and partly reciprocal biological features of the tumor. Whereas a higher AgNOR number is frequently found in fast proliferating and low differentiated tumors, a highly positive ER-status is often associated with more high differentiated tumors of low malignancy [19]. Connections between AgNORs and estrogen receptors have so far been discussed only on the case level but never on the cellular level. Looking at AgNORs and estrogen receptors on the case level a statistically inverse correlation between AgNOR amount and ER-positivity could be found [20]. This is no proof of a direct relationship of both markers on the cellular level. It is unknown if ER-negative breast cancer tumor cells contain more or fewer AgNORs than ER-positive cells. This can be investigated only by independently measuring AgNORs in ER-negative and ER-positive tumor cells.

For combined cellular investigation of both markers, a new staining procedure for a dual demonstration of AgNORs and ER in one histological slide is applied [21]. A method for the quantification of AgNORs in immunohistochemically stained nuclei by means of image analysis is established and the AgNOR content in ER-negative and ER-positive breast cancer tumor cells is compared. Furthermore, the relationship of AgNOR parameters and other prognostic indicators [Bloom-Richardson-Grading, rate of mitosis, growth fraction (Ki-67)] was investigated.

\section{Material and methods}

A set of 49 invasive (43 ductal; 6 lobular) breast carcinomas (G1: $n=14$; G2: $n=26$; G3: $n=9$ ) were analyzed. All patients (34-84 years; mean: 62 years) underwent surgery at the University Hospital Charité in 1994 and 1995. None of the patients received chemotherapy preoperatively.

The pathological report includes tumor size, nodal status, Bloom-Richardson-Grading and mitotic rate. Immunohistochemical analyses of estrogen receptors (ER-ICA), progesterone receptors (PR-ICA) and growth fraction (Ki-67) were carried out routinely. The
Table 1

Selected AgNOR parameters measured by the program "norcolor"

\begin{tabular}{ll}
\hline Parameter & Description \\
\hline NORNB & mean AgNOR number per nucleus \\
NOR_Kx & $\begin{array}{l}\text { mean number of nuclei containing } x \text { AgNORs, } \\
x=1, \ldots, 5\end{array}$ \\
NORAREA & $\begin{array}{l}\text { total AgNOR area per nucleus }\left[\mu \mathrm{m}^{2}\right] \\
\text { MAXNOR }\end{array}$ \\
$\begin{array}{l}\text { mean area of the biggest } \mathrm{AgNOR} / \mathrm{AgNOR}- \\
\text { MEANAREA }\end{array}$ & \begin{tabular}{l} 
mean area of the single AgNOR dot $\left[\mu \mathrm{m}^{2}\right]$ \\
\hline
\end{tabular}
\end{tabular}

cancer tissue was fixed in formalin $10 \%$ and embedded in paraffin. Slides of $3 \mu \mathrm{m}$ thickness were produced.

ER/AgNOR staining procedure was performed according to protocols published in this issue of ACP [21].

The AMBA software is part of the image analysis system AMBA and was developed at the Laboratory for Automated Image Analysis at the Institute of Pathology, University Hospital Charité, Berlin. The AMBA system is especially designed for histometric and karyometric measurements and consists of a personal computer, a frame grabber (Matrox Comet, Matrox Co. Canada), a color monitor (Sony Multiscan 17sf), a microscope (Jenaval, Carl Zeiss Jena $\mathrm{GmbH}$, Germany) and a video camera (Sony 3CCDColor Video Camera DXC-930P, Sony Co., Japan).

The program "norcolor" allows segmentation of AgNORs in immumohistochemically stained nuclei and automatically measures several AgNOR variables (Table 1). However, there had been initial problems in the segmentation of the ER-negative tumor cell nuclei. The RGB color image provided only suboptimal conditions for the segmentation of these yellowish structures. Thus, the three components of the RGB-image were tested for segmentation conditions. The green image demonstrated good segmentation conditions for both ER-negative and ER-positive nuclei. AgNOR segmentation was carried out within the red image. The observer is presented with the RGB-image during the whole measuring procedure.

The classification of tumor cells (ER-positive/ERnegative) was carried out in the RGB color image by the eye of the observer. As ER-positive cells were considered all tumor cell nuclei showing a red color, no matter if the staining was strong or weak. All other tumor cell nuclei were classified ER-negative. 100 tumor cell nuclei of ER-negative and ER-positive cells were measured, respectively.

Statistical analysis was performed using NCSS 5.1 statistics package (copyright 1991 by Dr. Jerry L. 
Hintze; 329 North 1000 East Kaysville, Utah 84037 [801] 5460445) and SPSS (SPSS Inc. USA). For the comparison of mean values, $t$-test was performed. Pearson's $r$ and Spearman's $\rho$ were calculated to evaluate the correlation between variables.

\section{Results}

\subsection{AgNOR content in ER-negative and ER-positive tumor cells}

Based on the measurements of AgNORs in ERnegative and ER-positive nuclei of 49 breast cancers a number of significant differences between ER-negative and ER-positive cells in terms of their AgNOR content was found. Basically, ER-negative cells contain a higher number of AgNORs (2.95 \pm 0.62$)$ than ERpositive cells $(1.49 \pm 0.26 ; p<0.0001)$ (Fig. 1). The majority of ER-positive cells contains only one AgNOR or AgNOR cluster (Fig. 2). ER-negative cells mostly contain two, three or four AgNORs.

Total AgNOR area per nucleus (NORAREA) is larger in ER-positive cells (Table 2). At first, this is contradictory to the findings that ER-positive cells contain a lower AgNOR count compared to ERnegative cells. There are both biological and methodological reasons for this. In terms of the area of the biggest AgNOR/AgNOR-cluster (MAXNOR), ER-positive cells clearly have higher values than ER-negative cells. It has to be pointed out that especially in ERpositive cells no single AgNOR dots rather only AgNOR clusters were measured. Single AgNOR dots (MEANAR) in ER-negative cells are smaller than in ER-positive cells.

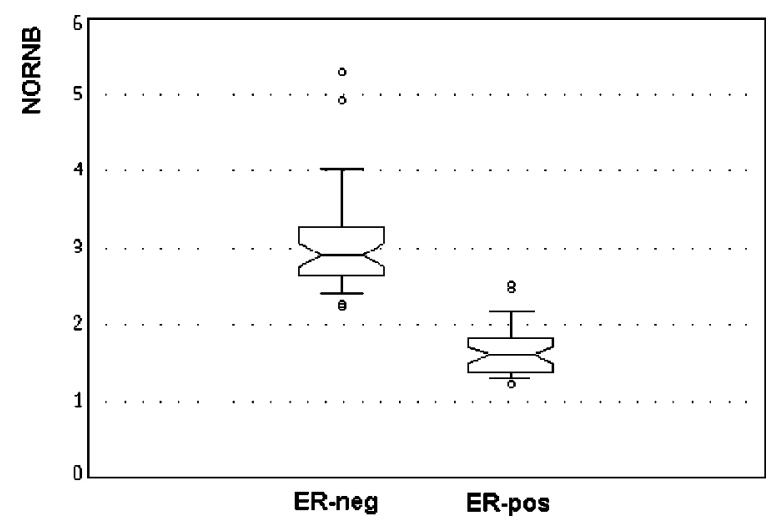

Fig. 1. Mean AgNOR number per nucleus (NORNB) in ER-negative (ER-neg) and ER-positive (ER-pos) tumor cell nuclei.
The correlation of the total AgNOR area per nucleus (NORAREA) and the AgNOR number per nucleus (NORNB) plotted for ER-negative and ER-positive cells (Fig. 3) shows that both cell populations can be clearly distinguished by measuring only these two AgNOR variables.

\subsection{Relationship between AgNOR content and ER status of the tumor}

A weak inverse correlation was recorded between the AgNOR number per nucleus (NORNB) of the whole tumor and the results of the Estrogen-ReceptorImmuno-Cytochemical-Assay (ER-ICA) $(r=-0.289)$ (Fig. 4). Looking at ER-negative and ER-positive cells seperately, in ER-negative cells the negative correlation between AgNOR number and ER-positivity of the whole tumor is stronger ( $r=-0.653)$. AgNOR number of ER-positive cells shows no correlation to the ER-ICA $(r=-0.008)$.

\subsection{Relation between AgNORs and other criteria of malignant potential}

The coherence of certain AgNOR variables in a correlation plot (separately viewed for the whole tumor, ER-negative cells and ER-positive cells) with other criteria of malignant potential, such as BloomRichardson-Grading (3, ., 9) (Fig. 5), nuclear grading $(1,2,3)$, mitotic rate (number/10 image sections) and growth fraction (Ki-67) [\%] (Table 3) was investigated. Noticeable correlation was exclusively found in the category of ER-negative cells.

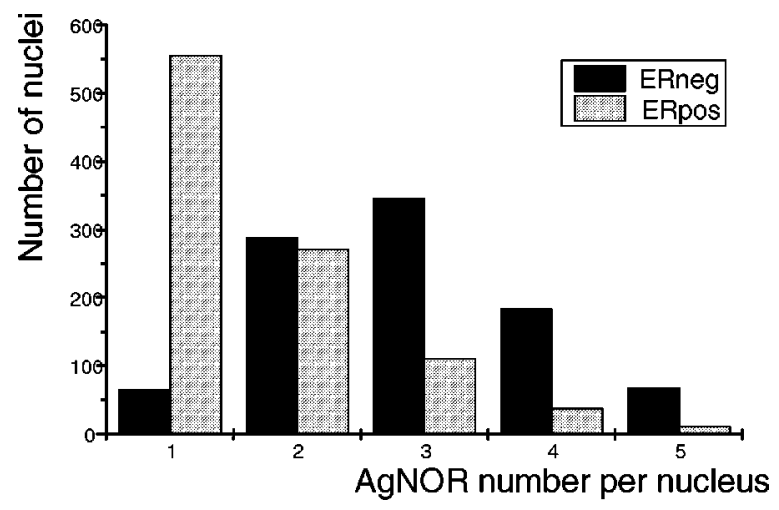

Fig. 2. Relative number of cells containing $n$ AgNORs $(n=$ $1, \ldots, 5)$ in ER-negative and ER-positive cells. 
Table 2

Parameters describing AgNOR area: mean (M), standard deviation (SD) and level of significance $p(t$-test)

\begin{tabular}{lccc}
\hline & \multicolumn{2}{c}{ Mean and standard deviation $(\mathrm{M} \pm \mathrm{SD})$} & $p(t$-test $)$ \\
\cline { 2 - 3 } & ER-neg. cells & ER-pos. cells & $4.80 \pm 1.65$ \\
\hline NORAREA, total AgNOR area per nucleus $\left[\mu \mathrm{m}^{2}\right]$ & $3.69 \pm 1.11$ & 0.0006 & $3.48 \pm 1.44$ \\
MAXNOR, area of the largest AgNOR/AgNOR-cluster per nucleus $\left[\mu \mathrm{m}^{2}\right]$ & $1.15 \pm 0.43$ & 0.0001 & $3.22 \pm 1.04$ \\
MEANAREA, area of the single AgNOR-dot $\left[\mu \mathrm{m}^{2}\right]$ & $0.82 \pm 0.32$ & 0.0001 \\
\hline
\end{tabular}

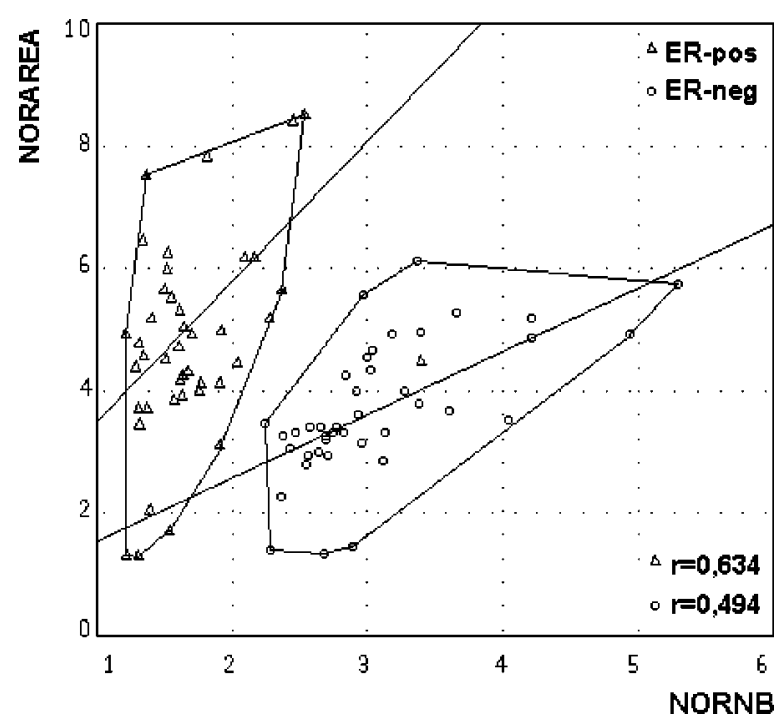

Fig. 3. Correlation between total AgNOR area per nucleus (NORAREA) and AgNOR number per nucleus (NORNB) in ER-positive (ER-pos) and ER-negative (ER-neg) cells.

\section{Discussion}

Since the introduction of the improved one step staining technique by Ploton et al. 1986 [7], AgNORs have become increasingly interesting as prognostic indicators. Many studies on AgNOR parameters in different organ tumors verify their importance [22]. First of all, AgNOR variables characterise the proliferation behaviour of malignant tumors [12]. Derenzini et al. $[13,14]$ demonstrated a strong direct correlation between AgNOR content and proliferation rates in many organ tumors. Moreover, AgNOR parameters provide information on cell differentiation [23]. Although AgNOR number and total AgNOR area are those parameters correlating with the proliferation rate [14], the direct proof of the prognostic predictivity is still pending.

Dual staining of ER and AgNORs leads to a reproducible and specific staining result, since there are no mutual influences of both individual staining methods [21]. It was concluded that the measurement of AgNORs in immunohistochemically marked nuclei is methodologically justified.

\subsection{AgNOR content in ER-negative and ER-positive tumor cells}

ER-negative breast cancer cells contain more AgNORs than ER-positive cells. Low grade differentiated cells show statistically higher AgNOR numbers. Taking into account the correlation between AgNOR number and tumor proliferation rates $[13,14]$ the ERnegative tumor cells are characterised as the faster proliferating cell population. Conversely, the lower AgNOR numbers in ER-positive cells correspond to a lower tendency of cell division.

The differences in AgNOR area of ER-negative and ER-positive cells are an expression of a more complex context which can be only insufficiently characterised by the measured area variables. How can ERnegative cells contain more AgNORs while having a smaller AgNOR area? A detailed view provides an interpretation model: (a) according to the MAXNOR measurements, more AgNOR clusters can be found in ER-positive cells. AgNOR clustering is basically connected with overestimation of the true area because of staining and measuring reasons. (b) The area of a single AgNOR dot (MEANAREA) in ER-negative cells is lower than in ER-positive cells. Considering the reverse effects of the cluster-dependent overestimation of the true area in ER-positive cells and smaller single AgNORs in ER-negative cells on the evaluation of the total area of AgNORs, the controversial measuring results can be explained.

Because total AgNOR area per nucleus (NORAREA) in ER-positive cells is subsequently overestimated, a discussion and interpretation of these findings is not useful. As mentioned above, the area of single AgNOR dots in ER-negative cells is lower than in ER-positive cells. Reeves et al. 1984 [23] showed that low differentiated cells have single AgNORs of a smaller area compared to cells with a higher differentiation. This is further proof of a higher malignancy of ER-negative cells.

A special clustering phenomenon in ER-positive tumor cells can be described. A strong clustering of AgNORs exclusively in highly differentiated cells of 


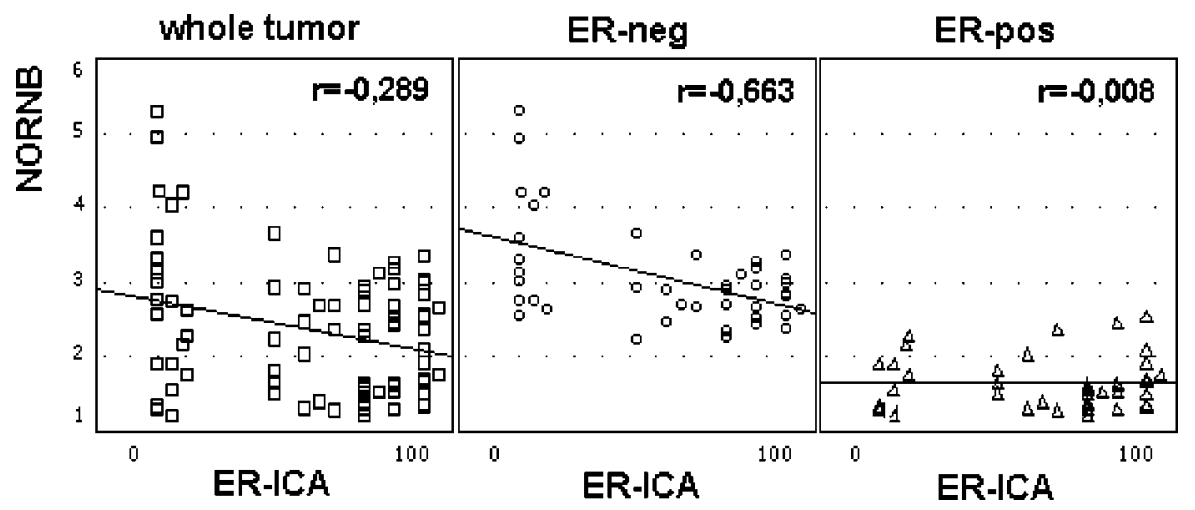

Fig. 4. Correlation between AgNOR number per nucleus (NORNB) and Estrogen-Receptor-Immuno-Cytochemical-Assay (ER-ICA) [\%] plotted for the whole tumor (left), ER-negative cells (middle) and ER-positive cells (right).

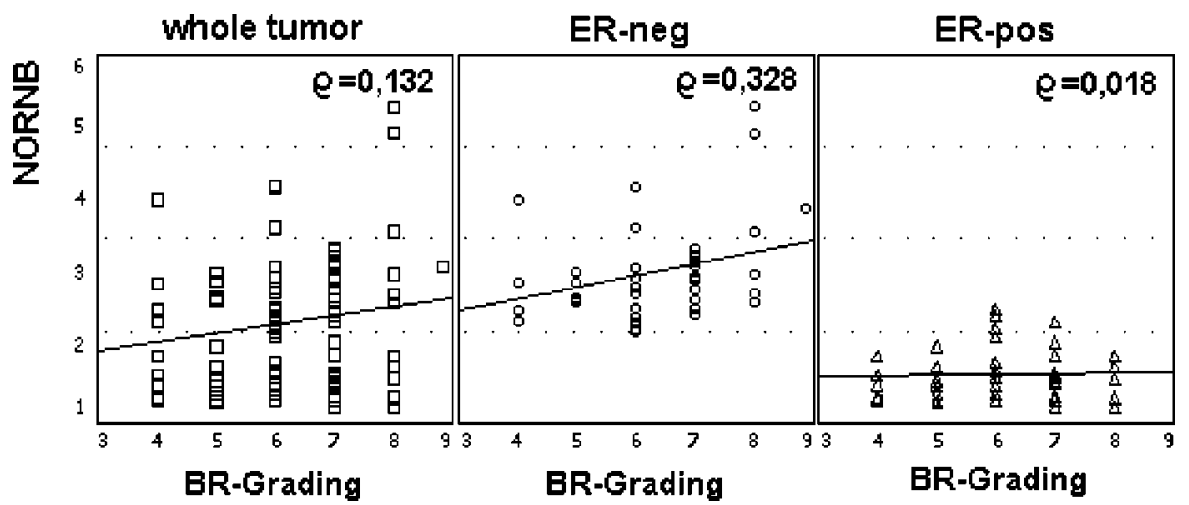

Fig. 5. Correlation between AgNOR number per nucleus (NORNB) and Bloom-Richardson-Grading (BR-Grading) $[4, \ldots, 9]$ plotted for the whole tumor (left), ER-negative cells (middle) and ER-positive cells (right).

urothelium was observed by Rüschoff et al. in 1994 [26]. It is widely accepted that ER-positive cells are better differentiated than ER-negative cells. In our investigations, a marked AgNOR clustering was only found in ER-positive cells. With an increasing ERpositivity of the whole tumor, the AgNOR cluster area becomes larger (Fig. 6). Thus, the clustering of AgNOR dots is considered to be a marker of a higher cell differentiation.

\subsection{Relation between AgNOR content and ER status of the tumor}

Looking at the relation between AgNOR parameters and ER-positivity of the tumors, it became necessary to differentiate between ER-negative and ER-positive cells (Fig. 4), because only a weak correlation had been reported. The higher the ER-positivity of the tumor, the less AgNORs can be found in ER-negative cells. It is concluded that a higher differentiation of the whole tumor also influences the proliferative activity of the more malignant ER-negative cells. There is no correlation between AgNOR number of ER-positive cells and ER-ICA. The higher the amount of the ER-positive tumor cells, the lower is the tendency for proliferation of the whole tumor. With increasing ER positivity, the proliferation of the ER-negative cells is restricted.

\subsection{Relation between AgNORs and other criteria of malignant potential}

AgNOR parameters (separately viewed for the whole tumor, ER-negative cells and ER-positive cells) and Bloom-Richardson-Grading, nuclear grading, mitotic rate and growth fraction (Ki-67) (Table 3) were compared. Surprisingly, correlation with all of the histopathological markers could be found exclusively in ER-negative cells. Increasing values of AgNOR number and total AgNOR area per nucleus in ER-negative cells with increasing malignancy of the tumor were 
Table 3

Correlation between AgNOR parameters (separately viewed for whole tumor; ER-neg cells and ER-pos cells) and other criteria of malignancy grade: Bloom-Richardson-Grading, nuclear grading, mitotic rate and growth fraction (Ki-67)

\begin{tabular}{|c|c|c|c|c|c|}
\hline & & \multicolumn{2}{|c|}{ Spearman's $\rho$} & \multicolumn{2}{|r|}{ Pearson's $r$} \\
\hline & & Bloom-Richardson-Grading & nuclear grading & mitotic rate & growth fraction (Ki-67) \\
\hline NORNB & Whole tumor & 0.132 & 0.186 & 0.186 & 0.221 \\
\hline mean AgNOR-number & ER-neg. cells & 0.328 & 0.249 & 0.313 & 0.286 \\
\hline per nucleus & ER-pos. cells & 0.024 & 0.191 & -0.010 & 0.002 \\
\hline NORAREA & Whole tumor & 0.102 & 0.069 & -0.025 & 0.084 \\
\hline total AgNOR area per & ER-neg. cells & 0.283 & 0.226 & 0.238 & 0.270 \\
\hline nucleus $\left[\mu \mathrm{m}^{2}\right]$ & ER-pos. cells & 0.054 & 0.091 & -0.175 & 0.055 \\
\hline MAXNOR & Whole tumor & -0.064 & -0.119 & -0.150 & -0.048 \\
\hline Mean area of the largest & ER-neg. cells & -0.115 & -0.118 & 0.023 & 0.012 \\
\hline $\mathrm{AgNOR} /$-cluster $\left[\mu \mathrm{m}^{2}\right]$ & ER-pos. cells & 0.011 & -0.033 & -0.231 & 0.110 \\
\hline
\end{tabular}

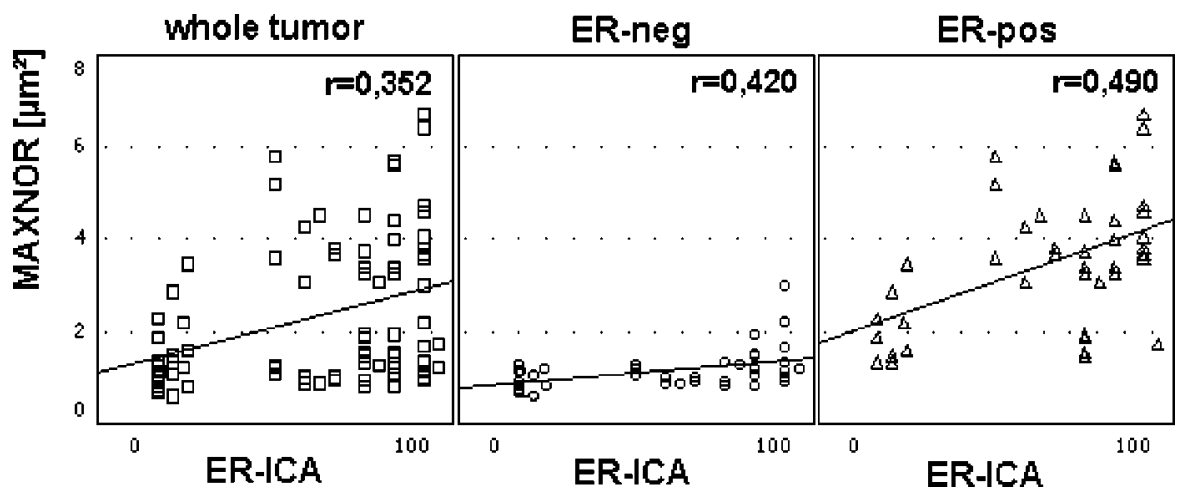

Fig. 6. Correlation between mean area of the biggest AgNOR/AgNOR-cluster per nucleus $\left[\mu \mathrm{m}^{2}\right]$ (MAXNOR) and EstrogenReceptor-Immuno-Cytochemical-Assay (ER-ICA) [\%] plotted for the whole tumor (left), ER-negative cells (middle) and ER-positive cells (right).

found. Based on these findings, AgNOR number and AgNOR area of ER-negative cells can be considered as additional parameters of malignancy grade in breast cancer. The fact that the AgNOR content of ERpositive tumor cells is not influenced by the level of tumor malignancy underlines the inferior role of this cell population with regard to tumor progression.

\subsection{Relation between ER status and growth fraction of the tumor}

The relations between ER-status and growth fraction of the tumor can still only be described indirectly. A significant correlation between AgNOR number or AgNOR area and Ki-67 assay was described by Dervan et al. 1989 [29] and Derenzini et al. 1990 [14]. A similar correlation for the Ki-67 assay was found in this study, but only for the ER-negative cell group. An identity of growth fraction and ER-negative cell group is not very likely. The growth fraction of the tumor cells, however, could be part of the quantity of the ERnegative cells (or vice versa). This requires further investigation.

\subsection{Comparison of ER-positive and ER-negative tumor cells}

AgNORs in ER-positive cells show a special distribution pattern. But this does not provide useful information: (a) Nuclei of this cell fraction contain fewer AgNORs compared to ER-negative cells. This is a sign of a lower proliferation activity. (b) ER-positive cells are carriers of special markers of differentiation such as estrogen receptors and AgNOR clustering. (c) There is no correlation between AgNOR variables and other criteria of malignancy grade.

AgNORs in ER-negative cells of human breast cancer have special characteristics. In relation to other features these cells can be characterised as the more malignant and possibly prognosis-dictating cell fraction: 
(a) The ER-negative cell fraction has a higher tendency to proliferate compared to the ER-positive cells due to higher AgNOR numbers. (b) Correlation between AgNOR parameters of ER-negative cells and other criteria of malignancy such as Bloom-Richardson-Grading and growth fraction (Ki-67) support these findings. (c) In ER-negative cells special markers of differentiation such as ER and AgNOR clustering are missing. (d) There is a possible relationship between ERnegative cells and the growth fraction (Ki-67). Thus, ER-negative cells probably contribute more to the progression of the tumor disease and furthermore to the prognosis than ER-positive cells.

Proof of the prognostic relevance could not be derived from this material. This requires further investigation. It seems to be useful to isolate a cell population, which dictates the prognosis of the tumor disease. Thus, it is suggested that AgNORs be measured exclusively in ER-negative cells of breast cancer.

\section{References}

[1] H.J.G. Bloom and W.W. Richardson, Histological grading and prognosis in breast cancer, Br. J. Cancer 11 (1957), 359-377.

[2] H.J.G. Bloom, W.W. Richardson and E.J. Harries, Natural history of untreated breast cancer (1805-1933). Comparison of untreated and treated cases according to histological grade of malignancy, Br. Med. J. 28 (1962), 213-221.

[3] C.K. Osborne, M.G. Yochmowitz, W.A. Knight and W.L. McGuire, The value of estrogen and progesterone receptors in the treatment of breast cancer, Cancer 46(Suppl.) (1980), $2884 \mathrm{~s}-2888 \mathrm{~s}$

[4] J.C. Allegra, M.E. Lippman, R. Simon, E.B. Thompson, A. Barlock, L. Green, K.K. Huff, H.M.T. Do, S.C. Aitken and R. Warren, Association between steroid hormone receptor status and disease free interval in breast cancer, Cancer Treat. Rep. 63 (1979), 1271-1277.

[5] S. Fakan and D. Hernandez-Verdun, The nucleolus and the nucleolar organizer region, Biol. Cell. 56 (1986), 189-206.

[6] W.M. Howell and D.A. Black, Controlled silver staining of nucleolar organizer regions with a protective colloid developer. A 1-step method, Experientia 36 (1980), 1014-1017.

[7] D. Ploton, M. Menager, P. Jeannesson, G. Himber, F. Pigeon and J.J. Adnet, Improvement in the staining and the visualization of the argyrophilic proteins of the nucleolar organizer region at the optical level, Histochem. J. 18 (1986), 5-14.

[8] M. Derenzini, F. Nardi and F. Farabegoli, Distribution of silverstained interphase nucleolar organizer regions as a parameter to distinguish neoplastic from non-neoplastic cells in human effusions, Acta Cytol. 33 (1989), 491-498.

[9] P. Hufnagl, H. Guski, R. Meyer, G. Wassilew and K. Wenzelides, Comparison of conventional morphometry and image analysis for the solution of histomorphometric problems, Gegenbaurs Morphol. Jahrb. 135 (1989), 145-150.
[10] J. Rüschoff, K. Plate, A. Bittinger and C. Thomas, Nucleolar organizer regions (NORs). Basic concepts and practical application in tumor pathology, Pathol. Res. Pract. 185 (1989), 878885.

[11] P. Hufnagl, H. Guski and H.J. Schulz, Measuring of AgNORs using image analysis, Zentralbl. Pathol. 140 (1994), 31-35.

[12] G. Brugal, Interpretation of proliferation markers, in: Compendium on the computerized cytology and histology laboratory, Tutorials of Cytology, 1994, pp. 234-240.

[13] M. Derenzini, A. Pession and F. Farabegoli, Relationship between interphasic nucleolar organizer regions and growth rate in two neuroblastoma cell lines, Am. J. Pathol. 134 (1989), 925-932.

[14] M. Derenzini, A. Pession and D. Trerè, Quantity of nucleolar silver-stained proteins is related to proliferating activity in cancer cells, Lab. Invest. 63 (1990), 137-140.

[15] W. Remmele, U. Hildebrand, H.A. Hienz et al., Comparative histological, histochemical, immunhistochemical and biochemical studies on estrogen receptors, lectin receptors and Barr bodies in human breast cancer, Virchows Arch. (A) 409 (1986), 127-147.

[16] E.V. Jensen and E.R. DeSombre, The diagnostic implicates of steroid binding in malignant tissues, Adv. Clin. Chem. 19 (1977), 57-89.

[17] M.E. Lippman and J.C. Allegra, Quantitative estrogen receptor analyses: The response to endocrine and cytotoxic chemotherapy in human breast cancer and the disease-free interval, Cancer 46 (1980), 2829-2834.

[18] M.R. Williams, J.H. Todd, I.O. Ellis et al., Oestrogen receptors in primary and advanced breast cancer: an eight year review of 704 cases, Br. J. Cancer 55 (1987), 67-73.

[19] J.C.E. Underwood, Oestrogen receptors in human breast cancer: review of histopathological correlations and critique of histochemical methods, Diagn. Histopath. 6 (1983), 1-22.

[20] J. Giménez-Mas, P. Gallego-Calvo and P. Sanz-Moncasi, AgNOR evaluation by image processing methods, Anal. Quant. Cytol. Histol. 18 (1996), 9-18.

[21] L. Günther and P. Hufnagl, Technique and reproducibility of a dual staining method for estrogen receptors and AgNORs, Anal. Cell. Pathol.

[22] H. Martin, P. Hufnagl, K. Wenzelides and M. Beil, AgNORs in cells of urothelial carcinoma of the bladder. A quantitave study using automatic microscopic image analysis, Zentralbl. Pathol. 137 (1991), 505-509.

[23] B.R. Reeves, G. Casey and S. Smith, Correlation of differentiation state and silver staining of nucleolar organizer regions in promyelocytic leukemia cell line HL-60, Cancer Genet. Cytogenet. 13 (1984), 159-166.

[24] G. Bigras, R. Marcelpoil, E. Brambilla and G. Brugal, Interest of targeting AgNORs measurement in cycling cells: in vivo cell kinetic evaluation of non-small cell lung cancer, Anal. Cell. Pathol. 11 (1996), 183-198.

[25] W.A. Mourad, N. Sneige, R.L. Katz and N.G. Ordóñez, Correlation of two AgNOR counts with Ki-67 labeling index, Diag. Cytopath. 10 (1994), 113-119.

[26] J. Rüschoff, G. Fauser, R. Knuchel and F. Hofstadter, AgNOR quantification with special reference to staining patterns, Zentralbl. Pathol. 140 (1994), 23-30. 
[27] D. Ofner, J. Rüschoff, D. Trerè, M. Aubele, M. Derenzini and K.W. Schmid, Standardized morphometric silver stained nucleolar organizer region associated proteins (AgNOR) analysis basic concepts, Pathol. Res. Pract. 106 (1995), 236-238.

[28] M. Aubele, G. Auer and U. Jutting, Prognostic value of AgNORs in breast cancer, Zentralbl. Pathol. 140 (1994), 55-60.
[29] P.A. Dervan, L.G. Gilmartin, B.M. Loftus and D.N. Carney, Breast carcinoma kinetics: argyrophilic nucleolar organizer region counts correlate with Ki-67-scores, Am. J. Clin. Pathol. 92 (1989), 401-407. 


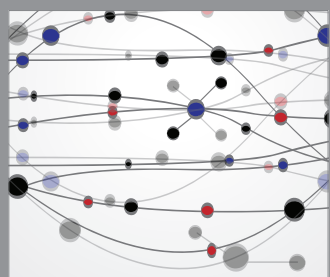

The Scientific World Journal
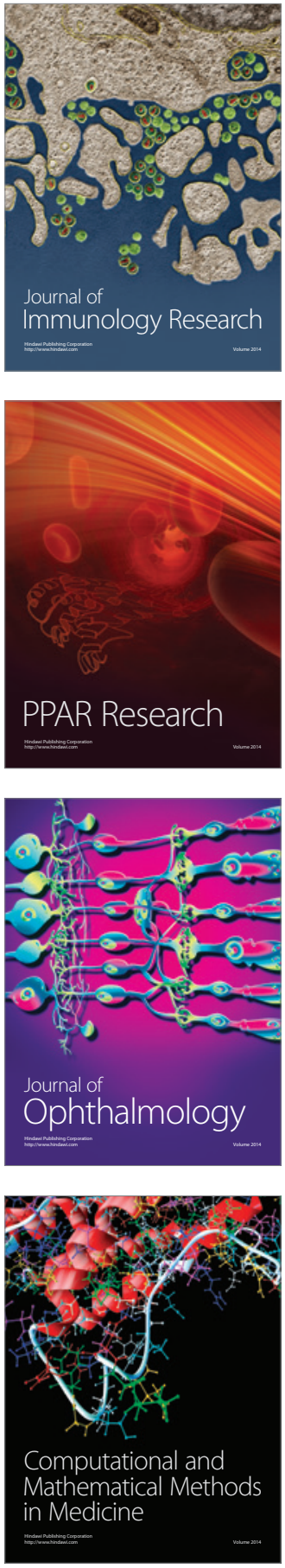

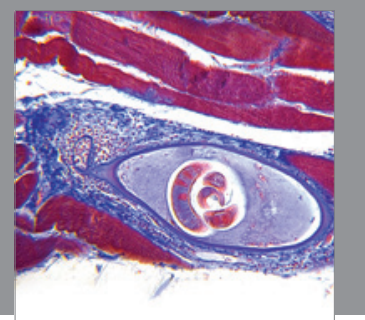

Gastroenterology

Research and Practice
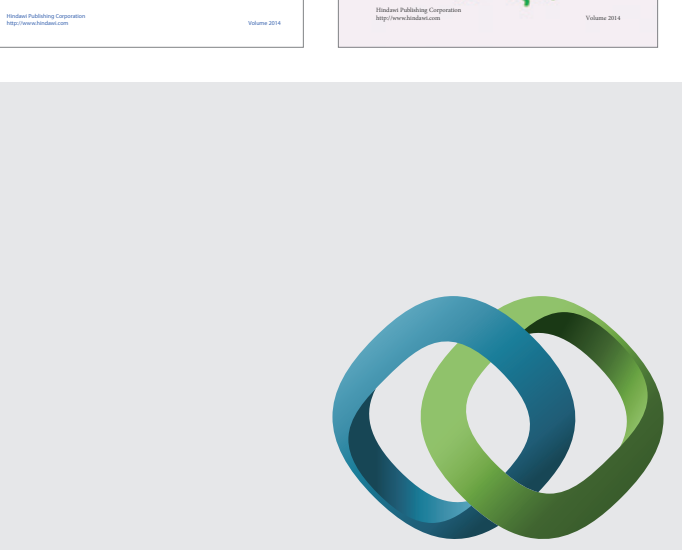

\section{Hindawi}

Submit your manuscripts at

http://www.hindawi.com
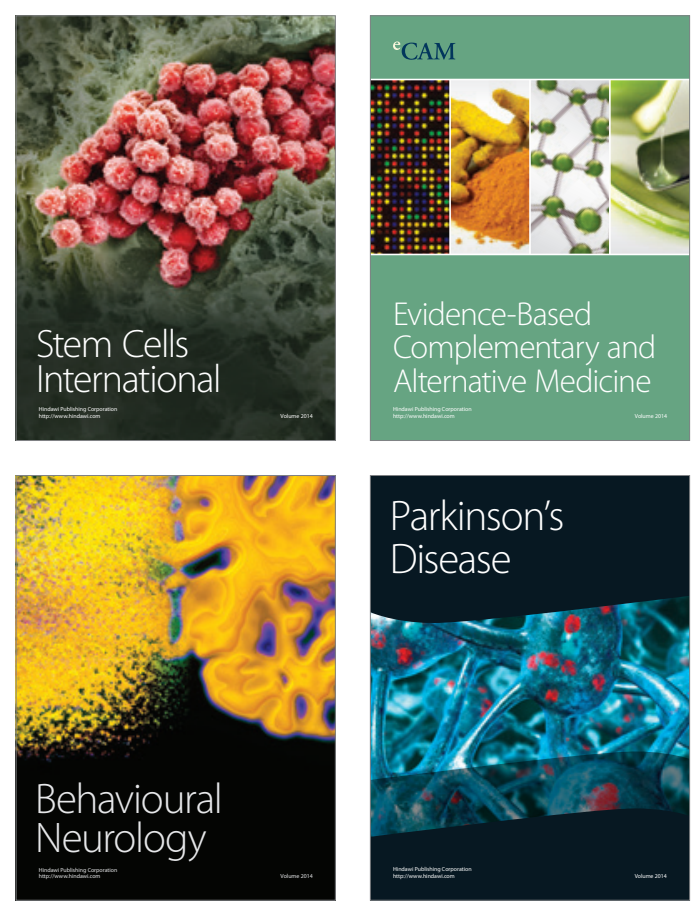

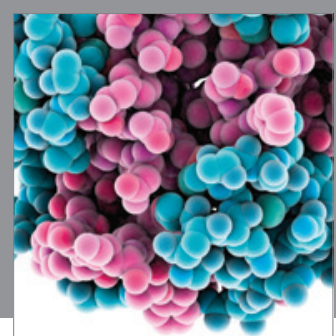

Journal of
Diabetes Research

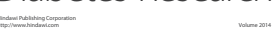

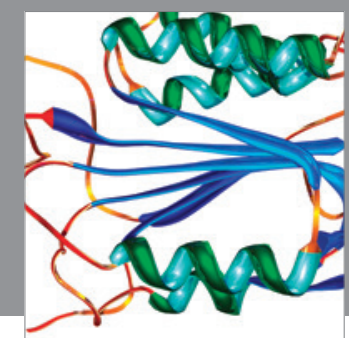

Disease Markers
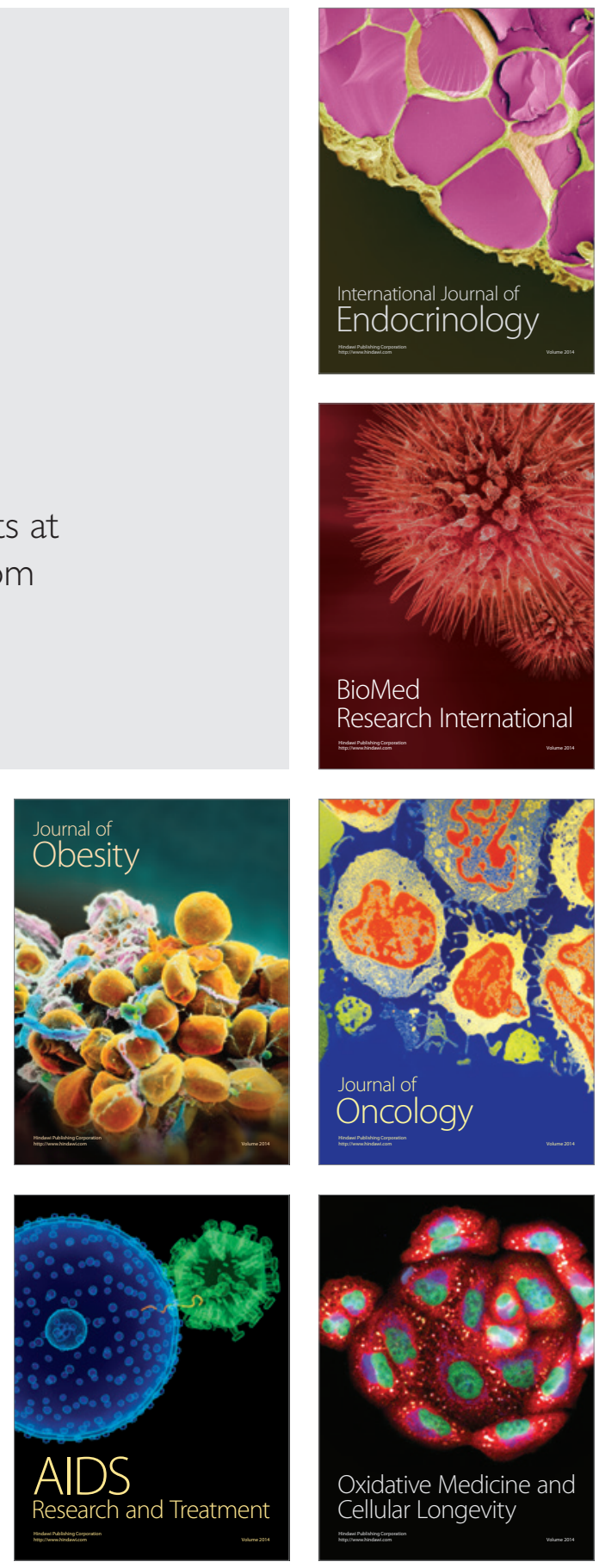